\title{
THE GOLDEN RAIN OF PUSHYK'S POEMS
}

\author{
OLHA SLONOVSKA
}

Pushyk S. Ya dlia Vkrainy Zhyv: u 2 t.

[For Ukraine I lived: in 2 vols.]

/ Olha Slonovska, editor and author of foreword

"Zolotyi Doshch Pusykovykh Poezii"

[The Golden Rain of Pushyk's Poems].

Misto-NV, Ivano-Frankivsk, 2019.

Throughout his last days, Stepan Hryhorovych Pushyk sought to polish and even publish his poems now included in the two-volume collection entitled "Ya dlia Vkrainy Zhyv!" ("For Ukraine I lived!"); he selected a considerable number of poems, placed them into a thick folder and spent hours working on them at the balcony of his apartment; also, he meticulously edited and polished his favorite, previously published, poems. I remember him confessing that he would implement all his plans if God would grant him just a few more months! Stepan Hryhorovych was a wondrously industrious person, a true workaholic, so his "napoleonic" plans did not surprise me. However, when he called me late at night, just within a day of his death, making an unexpected suggestion that I personally add the final touches to his last book of verse, my heart missed a beat: Stepan Hryhorovych would never make such a request without having a good reason for that! I refused saying that I would not dare to edit his poems and that only the author themselves is capable of doing such a job better than anyone else, but Stepan Hryhorovych was so deeply hurt by my reluctance that, nolens volens, I had to agree: "I will do it; the book will be published under my edition but only on condition that every nuance is approved by Pushyk!"

Recollections of our midnight conversation kept me awake till morning. Somehow, as if it were reality, I could see myself walking with Stepan Hryhorovych in the park; he was disturbed to see that they were mindlessly cutting down the century-old lindens and were also going to move on to the larches saying that all those trees were snags; this was obviously a lie because larch timber is known to be a very precious material, which is why it was neither a mistake nor negligence - the predators had avaricious plans; as regards calling the bare larches snags, it was also a lie: larches always fall off for the winter! I also recalled the wild ducks which some kind people used to feed on bread every day in the winter; the naïve birds used to waddle from the lake to the food store every day to secure themselves a portion of food. One night some villains gave the ducks some bread soaked in vodka, then caught them and wrung the poor birds' necks! Stepan Pushyk ranted and raved about that; his voice sounded heart- 
rending as urged his students not to do evil, to save every bird, insect, or grass blade! It was not without reason that I feared for the poet's health: God forbid he might fall ill!

Stepan Hryhorovych knew many unique folk names of mountains, torrents brooks, and gorges. Once he declared that there was golden rain blossoming and that he had never seen such thick blossom before. In fact, it was forsythia blossoming, which Stepan Hryhorovych also frequently mentions in his diary. Obviously, it was his favorite flower and he might have come up with the name "golden rain" himself, but how accurately this name reflected incredible beauty: it looked like golden rain indeed, with its elongated petals shaped like dew drops; untold wonder! "April 4, 1989. Thursday. How very cold and humid this Holy Week is! Rains. Apricot and plum trees are all in bloom. This year golden rain broke into blossom in March", "February 27, 1990. Tuesday. It rained at night and at dawn; everything has been washed... In the yard, a bush of golden rain has broken into blossom; behind the house, the willow has sprouted".

By nature and character, Stepan Hryhorovych was a real molfar (in Hutsul culture, a practitioner of folk magic) and a prophet: not once did something he said in passing come true to the smallest detail. He was considered a knowledgeable person, well-read, a walking encyclopedia! He could hold an interesting conversation on practically any topic. He did not mind talking to common people, povertystricken or homeless, though he could easily talk to academics as well. He worked with inspiration, without days off, holidays or at least short breaks. He hated hospitals and health resorts. He used to say it was there that his body and mind weakened. On the eve of his own death, he telephoned all his friends and acquaintances: as usual, he had an unmistakable premonition of the unavoidable.

Overnight August 13 to 14, 2018 Stepan Hryhorovych Pushyk, a titan of a man and a legend in his lifetime, passed away. Ivano-Frankivsk will never be the same without this restless, rebellious, nationally-conscious man, who managed to remain extremely active to the last. During his extremely stressful and difficult life, he helped very many Ukrainians by kind words, moral support, advice or selfless acts. When the anti-terrorist operation was launched, he willingly donated UAH 16,000 to Ukrainian soldiers! Stepan Hryhorovych was no ordinary man, at times too harsh in standing up for justice, but always honest, truthful and decent. He loved Ukraine, and Ukraine loved him.

In his "Autobiography", Taras Shevchenko wrote: "The story of my life constitutes part of the history of my Fatherland." Stepan Pushyk could have said the same about himself because he had to experience many momentous, difficult, horrifying events. Our talented fellow countryman was born during wartime. Hardly had little Stepan turned two years old when his native Vyktoriv Village became a living hell: the advancing Soviet Army mortared the way for the infantry; Hryhorii Pushyk's family had no chance of surviving the shell attack since there was a German command car near their house. They fled in great panic, the father carrying his baby in his arms and a bundle of pillows and blankets on his back. When the artillery shelling stopped, it turned out that a splinter of a rocket fired by a Katyusha had got stuck inside one of the pillows: the coincidence saved not only Hryhorii, but also his little son Stepan.

During the post-war years, the Soviet government waged a campaign of terror in a frantic effort to strengthen its position ruthlessly disposing of the Bandera guerrillas across the whole of Halychyna, including Pushyk's hometown. A native of Halychyna, he witnessed his patriotic fellow villagers dying for their native land, so he could learn at his mother's knee about sacrificial love of Ukraine as well as about hatred for cruel invaders. Stepan's friend's parents kept a whole arsenal of weapons under their barn, so the two little rascals sneaked a whole pail of unused cartridges from there. As regards propaganda literature in support of the Ukrainian Insurgent Army, it was sometimes brought for Stepan's father by Marko Boieslav. The cautious Hryhorii hid those priceless papers inside the thatched roof of his house. His little son noticed it, though it seemed that at that age the boy was only interested something like baby sparrows.

Stepan's mother and grandmother knew an infinite number of songs, fairy tales, and legends. The child's impressionable soul luxuriated in the generous treasury of folk imagination and wisdom. Thus, heredity had a significant influence on the character and life of the now-famous lyricist, author of numerous books of fiction and research studies. 
God did not spare Stepan Pushyk any of his best gifts - be it physical appearance, height, intellect, strength, success, or talent. Such lucky individuals are said to have been kissed on the crown by God. The historic past of Pushyk's small fatherland also played an important role: the old princely town of Halych; legends, folk tales, and fairy tales, which did survive till the 20th century; recent events illuminated with a halo of glory surrounding Ukrainian Sich Riflemen; the sacrificial fight of the Ukrainian Insurgent Army... In addition, Vyktoriv has always welcomed amateur talent shows; in fact, it was there that the world-renowned composer Denys Sichynskyi created a unique village choir as early as in 1901.

Stepan Pushyk's first book entitled "Zelena Khvoia" ("Green Needle Leaves") was published in 1964 in an edition of as few as 25 copies on the recommendation of the Intelligentsia Club. However, one could pay a high price for a self-published edition because by that time "the Brezhnev freeze" had already replaced "the Khrushchev thaw", with the leading critic from the USSR roaring with unconcealed aggression at a rostrum: "You shall not see a thaw! The thaw is over!".

At that time, Stepan Pushyk was a newly enlisted soldier serving at a missile base in Moscow Oblast; he was lucky to be right in the communist liar where KGB officers would rarely dare to search for renegades. Having been granted a furlough, Stepan Pushyk headed home through Kyiv. When he came to the editorial office of the Ukraina magazine in order to submit his poems, he found the literary editor Natalka Kashchuk crying bitterly: "Our best guys have been arrested. Stus and Chornovil will be put on trial!" Was Pushyk also running the risk of finding himself in a place where goats had their horns straightened? He was because the totalitarian machine worked like an insatiable mincer, so one did not necessarily have to be guilty of acting against "the party and the people" to be sent to prison. However, the guardian angel protected the soldier like the apple of his eye: at those terrible times Stepan Hryhorovych did manage to publish his first real book of poetry in one packet with the thin booklets of other authors; despite this, the book had a conspicuous title - "Molodi Hromy" ("Young Thunderstorms"). You may notice its similarity to the title of Lina Kostenko's book called "Peredhrozzia" ("Time before a Thunderstorm"), which the author was forced to change to "Nepovtornist" ("Inimitability"). Censorial authorities monitored every single word, deciphered the slightest hints or ambiguous messages. Even in the song "Dva Kolory" ("Two Colors") (lyrics by D. Pavlychko, music by O. Bilash) haters managed to find references to the Bandera flag! Thunderstorms, who are young, could also be interpreted as a rebellion of the 70s generation, as an explicit threat to the rotten totalitarian system, which was relentlessly heading towards a precipice.

During the same period, which was "not the times of Batu Khan" (as per Oleksandr Smoliak), Stepan Hryhorovych got into big trouble with the self-published book, which was then popular with young people, and had a narrow escape from a disciplinary battalion, which was considered a significantly harsher punishment than prison. Distressed by the horrible prospect, the soldier was prepared for the worst. Suddenly his friends came running to the barracks: "Your song is being performed on TV!" Stepan rushed off the bed like a scalded cat; seeing the television program for himself, he got taken aback: in the Pillar Hall there stands the handsome Dmytro Hnatiuk and the host announces: "Lyrics by Stepan Pushyk, a soldier of the Soviet Army; song called'Yablonevaya Osen' ('Apple Autumn')". As if in a trance, he listened to his own song being performed. Capturing the faces of the spectators, the camera slid along the box: the Political Bureau headed by Leonid Brezhnev were applauding! Stunned by his success, Stepan ran out of the barracks, did a few most difficult exercises on a pull-up bar and cried out: "Dare send me to a disciplinary battalion; aha, dream on!"

Even after becoming famous in Ukraine and receiving numerous awards, Stepan Hryhorovych Pushyk always remained opposed to the current government. In 1987, the Ukraina magazine published Pushyk's article entitled "Pamiat Sovisti" ("The Memory of Conscience"), in which the ideology secretary of the Regional Committee of the Communist Party was given a hard time because many ancient churches across the region had gone up in flames; consequently, that issue of the national periodical was not available at any newsagent's in Ivano-Frankivsk Region. Neither was it sent to Precarpathian subscribers. Being scared stiff, Ivano-Frankivsk Region Council made every effort to prevent the reader from accessing "The Memory of Conscience". 
A winner of the Taras Shevchenko National Prize; a recipient of the literary awards named in honor of Ivan Franko, Pavlo Chubynsky, Myroslav Irchan; a recipient of the Wolanyk and Shwabinsky International Literary Award (the Ukrainian Free University Foundation in New York), a deputy of the Verkhovna Rada of the First Democratic Convocation, a professor at Vasyl Stefanyk Precarpathian National University, Merited Artist of Ukraine, a chevalier of the Order of Merit (2nd class), chevalier of the Order of Merit (3rd class), recipient of the jubilee medal "25 years of the Independence of Ukraine"- Stepan Hryhorovych Pushyk was constantly noted for significant creative achievements: research papers on "The Tale of Igor's Campaign", one hundred and fifty poems set to music, novels, wonderful books of fairy tales, proverbs and sayings, poems, short prose pieces, anthologies of laudable scope presented in six volumes and seven books. At his respectful age, the author still possessed immense creative power. He was finishing "Busova Knyha" ("Bus' Book"), exploring where the author of "The Tale of Igor's Campaign" was buried, finishing another book of poetry, organizing his diaries. Stepan Pushyk had no time for rest, nor did he care for his health. This resonates with Ernest Hemingway, a Nobel Prize winner and world-famous American writer, who said that you will never be a great writer if you fear dying.

Nowadays it is no secret that a genuine artist tends to live in an imaginary rather than real world and is able to see magic in mundane actions; thus a clump of dahlias left in the ground in frosty weather reminds the writer of carol singers:

Дні осінні притерті, мов шини,

Fall days worn out like tires,

Кущ шипшини, мов кадр із кіно.

A briar bush like a movie still.

А навипилечки дружно жоржини

And on tiptoe the dahlias

Колядують комусь під вікном.

Are singing carols beneath someone's window.

Stepan Pushyk believes that birds and animals are considerably closer to paradise than people affected by progress, avarice and rationalism:

Причайлась зажурена птаха.

A gloomy bird is lurking.

Одинока, забута, сумна,

Lonely, forgotten, sad;

I хмарина загубленим лахом

With a forlorn laugh, a cloud

Ïй лепече, що завтра зима-

Is muttering to her that tomorrow is winter -

or:

Там, на Верховині, - всі високі!

There, in Verkhovyna, everyone is tall!

май манив закоханих у рай.

May was luring the lovers into paradise

Господи, звіряток яснооких

God, do not punish little clear-eyed animals

За гріхи невинні не карай.

For harmless sins.

Stepan Pushyk possessed the ability to feel happy about ordinary things:

Передгроззя небо голубе

Blue sky before a thunderstorm.

Понесли, як проліски, дівчата.

The girls carried it along like snowdrops. 
And how deep was his feeling for mountains and wildlife, as well as for a Hutsul - a highlander in the Carpathians, who lives in harmony with nature:

У кошарах говорять овечі дзвінки.

In the barns, the sheep bells are talking;

Стеле річка рушник у міжгір'ї світанню.

Between the mountains, the river is spreading a towel for the dawn.

Кінь у небі читае зелені зірки,

The horse is reading green stars in the sky,

I читання його переходить в іржання.

And his reading turns into neighing.

Може, щось у Небесного просить Царя?

Maybe he is asking the Heavenly King for something?

Може, й він розуміє ранкову мохитву?

Maybe he also understands morning prayer?

Хоче він, щоб впряглась в його бричку Зоря,

He wants the Morning Star harnessed to his britzka

А він вивезе Сонце на гору блакитну?

And he will take the Sun to a blue mountain

Never did Stepan Pushyk tolerate anyone's meanness, falsehood; he disliked double-faced people and despised time-servers:

При Австрії изей хрунь австрійцеем був,

Under Austria this swine was an Austrian;

При Польщзі-по́ляком, щзо корінь забув,

Under Poland, a Pole who forgot his roots;

При німияях німцеем... Й ось: він - русскій! Ваһ!

Under Germans, a German...Lo and behold: he is a Russian!

Ще стане українцеми? Боже збав!

Will he also become a Ukrainian? God forbid!

Like any other artist, Stepan Hryhorovych was most concerned with realizing his talent. During the last years of his life, he exerted himself but was nevertheless dissatisfied with his results and achievements complaining that there was increasingly too little time to finish everything up because he always began writing a few works simultaneously. Despite this, however, S. Pushyk was well aware that artistic activity is about quality, not quantity:

Ти не плач, не зітхай, що не пишеться!

Don't you cry, don't sigh when you don't feel like writing!

Віриі, друже, не возять возами.

Poems, my friend, need not be produced by the cartload.

Подумай лище, щю залишиться

Just think what will be left over

3 тих рядків, які ми написали.

From those lines we have written.

Stepan Hryhorovych had phenomenal intuition and was an innate workaholic: even within a few hours of his death he worked on an article for the Dzvin journal ("The Bell") and the poet's last piece ("Parashka") dates back to 1 August 2018.

Stepan Pushyk's talent was undeniable because like any true artist he had a prodigious memory, a keen power of observation, the ability to sympathize with real people, his contemporaries, without distancing himself from them, without despising his own literary characters, who did not always manage to overcome adversities. This might be the reason why Hryhir Tiutiunnyk describes the mystery of his hard-earned talent as pain or, more precisely, as an artist's high pain threshold and willingness to stand up for anyone who is in trouble or poverty. Pavlo Zahrebelnyi, whose historical novels are by far the best in Ukrainian literature, also made an insightful observation that an artist 
always has an extraordinary life: one who has not suffered, who somehow managed to escape adversities cannot become an interesting writer for the simple reason that they have nothing to tell their readers about. Ernest Hemingway wrote the following about literary achievements like those of Pushyk's: "All good books are alike in that they are truer than if they had really happened; and after you are finished reading one, you will feel that all that happened to you and afterwards it all belongs to you: the good and the bad, the ecstasy, the remorse and sorrow, the people and the places and how the weather was. If you can get so that you can give that to people, then you are a writer."

As regards Stepan Pushyk's creative heritage, many works have so far remained unpublished considerably outnumbering the ones published during his life: the manuscript of Stepan Pushyk's diary, probably the longest one in the world, is composed of three hundred volumes. They include memoirs, which are now very popular among readers because an epoch is depicted and analyzed by an eyewitness at a very close distance.

Ukrainian nine-grade students use Pushyk's translation and interpretation of "The Tale of Igor's Campaign". A wide selection of Pushyk's works has been included in the recent anthology of Ukrainian literature published by "Litera" ("Letter"). It would be good if all teachers used this very book and promoted it at schools. Recently, Pushyk's comprehensive study about the burial site of Osmomysl's son, Prince Volodymyr Yaroslavych, author of "The Tale of Igor's Campaign", has created a stir among researchers. Today, on Pushyk Hill, somewhere near this bard, lies Stepan Hryhorovych himself - willed to be buried in his native Vyktoriv, which is an honor for his hometown.

People whose destiny is similar to Stepan Pushyk's always come to this world on a great mission, which is never easy to accomplish, which they themselves cannot fully understand, which is extremely exhausting but necessary not for a single person or the bearer of the talent themselves, but for a whole nation. Let us consider Pushyk's unique songs alone: they have become national and will be performed in Ukraine for centuries because they are perceived as original, sacred. Researchers will long continue to refer to Pushyk's findings about "The Tale of Igor's Campaign". For decades, the former students of this extraordinary researcher and collector of folk wisdom will continue to tell their children and grandchildren amazing stories about him.

It is laudable that Ivano-Frankivsk City Council has resolved issues associated with placing a commemorative plaque on the house where Stepan Hryhorovych lived; on Aleia Slavy (Avenue of Glory) there is a star in his honor; a competition has been held to choose a design of a bust in memory of the poet; Ihor Tsependa, president of Vasyl Stefanyk Precarpathian National University, has allocated funds for publishing a two-volume collection of Stepan Pushyk's poems entitled "Ya dlia Ukrainy zhyv!" ("For Ukraine I lived!").

Talented poets do not die. They live in the hearts of contemporaries, talk to us through the medium of their verses, give us aesthetic satisfaction and joy.

Address: Olha Slonovska, Vasyl Stefanyk Precarpathian National University, 57 Shevchenko St., IvanoFrankivsk, 76025 Ukraine.

E-mail: olha.slonovska@ukr.net

Received: May 12, 2020; revised: September 20, 2020.

Слоньовська Ольга. Золотий дощ Пушикових поезій. Журнал Прикарпатського університету імені Василя Стефаника, 7 (2) (2020), 107-112. 